\title{
EFEKTIVITAS PELATIHAN MEMBUAT MEDIA PEMBELAJARAN INTERAKTIF DENGAN MACRO POWERPOINT BAGI GURU
}

\author{
Indah Purnama Sari ${ }^{1(*)}$, Anindita Trinura Novitasari ${ }^{2}$, Zaeni Miftah ${ }^{3}$ \\ Universitas Indraprasta PGRI, Indonesia ${ }^{1}$ \\ STKIP PGRI Bangkalan, Indonesia ${ }^{2}$ \\ STIKOM Cipta Karya Informatika, Indonesia ${ }^{3}$ \\ indahps.unindra@gmail.com ${ }^{1}$, aninditatrinura2015@gmail.com ${ }^{2}$, zaenimiftah02@gmail.com ${ }^{3}$
}

$\begin{array}{ll}\text { Received: } & 29 \text { Februari } 2020 \\ \text { Revised: } & 15 \text { Maret } 2020 \\ \text { Accepted: } & 17 \text { Maret } 2020\end{array}$

\begin{abstract}
Media pembelajaran memiliki peran penting dalam keberhasilan proses pembelajaran. Di era yang serba digital ini siswa cenderung lebih menyukai pembelajaran yang berinteraksi dengan computer, sehingga guru perlu dibekali kemampuan membuat media pembelajaran interaktif dengan Macro Powerpoint. Penelitian ini bertujuan untuk mengetahui efektivitas pelatihan yang telah dilaksanakan oleh guru-guru di SDN Demangan 2 Bangkalan, dengan melakukan analisis pengaruh factor instruktur dan materi pelatihan. Penelitian ini melibatkan semua guru di SDN Demangan 2 Bangkalan yang menjadi peserta pelatihan. Data primer diolah kemudian dianalisis dengan teknik regresi linier berganda. Hasil penelitian menemukan bahwa dua variable independen (instruktur dan materi) yang diduga mempengaruhi efektivitas pelatihan ternyata secara simultan berpengaruh signifikan walaupun hanya factor instruktur yang berpengaruh signifikan. Hal ini menunjukkan bahwa pengetahuan dan kemampuan berkomunikasi dari seorang instruktur lebih urgen dibandingkan materi pelatihan itu sendiri. Sebuah materi pelatihan yang memiliki tingkat kesulitan tinggi harus disertai dengan instruktur yang memiliki kompetensi untuk membuat materi yang berat menjadi lebih sederhana.
\end{abstract}

Keywords: Instruktur, Materi, Efektivitas Pelatihan, Media Pembelajaran Interaktif

(*) Corresponding Author: Indah Purnama Sari, indahps.unindra@gmail.com, 081296421405

How to Cite: Sari, I. P., Novitasari, A. T., \& Miftah, Z. (2020). Efektivitas Pelatihan Membuat Media Pembelajaran Interaktif Dengan Macro Powerpoint Bagi Guru. Research and Development Journal of Education, 6(2), 31-37.

\section{INTRODUCTION}

Salah satu metode pembelajaran klasikal yang paling sering digunakan oleh guru adalah metode ceramah. Bila dibandingkan dengan metode klasikal lainnya, metode ceramah memiliki banyak keunggulan utamanya dalam hal efisiensi waktu. Dengan metode ceramah guru dapat mengontrol kecepatan mengajar karena durasi waktu sepenuhnya dikendalikan oleh guru. Hal ini akan lebih memastikan bahwa target materi pembelajaran akan tercapai. Selain itu, kedudukan guru yang dominan di kelas akan lebih memudahkan guru dalam mengontrol perilaku belajar siswa. Namun sayangnya, jika tidak dikelola dengan baik, metode ceramah justru akan menimbulkan gejala-gejala negatif.

Gejala yang dimaksud adalah siswa menunjukkan perilaku-perilaku negatif yang bersumber dari kejenuhan atau rasa bosan, misalnya gelisah, tidak tenang, dan berusaha mengalihkan kebosanannya dengan cara mengajak teman sebangkunya berbicara. Guru 
tak lagi dihiraukan, terkadang siswa berpura-pura menyimak guru namun sebenarnya sudah memiliki pokok bahasan lain dengan lawan bicaranya. Lambat laun akan semakin banyak siswa yang saling berbicara sehingga menimbulkan keributan di kelas. Guru yang menyadari bahwa siswanya mulai tidak fokus pun akan menegur atau mengingatkan kelas. Setelah ditegur, biasanya kelas akan kembali tertib, namun hal ini tidak akan berlangsung lama. Realitanya, kebosanan tidak hanya menimpa siswa, guru juga kerap dirundung kebosanan yang dicirikan oleh tidak semangat mengajar, absensi guru yang tidak wajar (mencari-cari alasan tidak masuk mengajar), saat bel masuk kelas tidak langsung menuju kelas namun masih berlama-lama di ruang guru, serta sengaja menyelesaikan jam mengajar lebih cepat dari waktu yang ditentukan.

Kebosanan guru ini dipengaruhi oleh banyak factor, seperti kelelahan, gaya mengajar yang monoton, kurang update terhadap perkembangan informasi, teknologi, dan pengetahuan, kurang terampil dalam menggunakan media pembelajaran, serta kurangnya kreativitas untuk menciptakan pembelajaran yang lebih segar. Dengan kata lain, guru tidak boleh terkungkung oleh buku teks semata, harus mengembangkan wawasan dari beragam sumber informasi, termasuk meningkatkan literasi digital. Guru juga dituntut lebih kreatif mengembangkan kompetensi pedagogik dalam proses pembelajaran (Uno \& Mohamad, 2011). Selain itu guru juga perlu meningkatkan kreativitasnya dalam mengembangkan media pembelajaran. Salah satu penghambat terciptanya media-media pembelajaran yang kreatif dari para guru adalah adalah terbatasnya dana yang dibutuhkan untuk membuat/merancang media pembelajaran (Soenarko, Wiguna, \& dkk, 2018).

Menurut Schramm, media dipandang sebagai teknologi pembawa pesan (informasi) yang dapat dimanfaatkan untuk keperluan pembelajaran, adapun Briggs mendefinisikan media pembelajaran sebagai sarana fisik untuk menyampaikan isi/materi pembelajaran (Yamin, 2013). Jadi, penggunaan media tidak menggantikan peran guru sebagai tutor, media hanya bersifat membantu guru agar pesan materi dapat tersampaikan dengan lebih baik. Media pembelajaran merupakan salah satu cara mengatasi kelemahankelemahan dalam proses pembelajaran.

Untuk mengatasi kelemahan dalam pembelajaran yang menggunakan metode ceramah, penggunaan teknologi informasi (komputer) dalam pembelajaran dipandang sebagai pemecahan yang sesuai (Wena, 2009). Penggunaan alat bantu komputer sebagai salah satu media audio visual dapat mengurangi verbalisme yang sering terjadi jika guru hanya menggunakan alat bantu visual saja tanpa memunculkan efek audio (Sari, Sari, \& Miftah, 2019). Sayangnya kemampuan guru dalam mengekplorasi teknologi informasi (komputer) dalam pembelajaran masih sangat sederhana, yang umumnya hanya berbentuk slide power point.

Salah satu cara untuk meningkatkan kompetensi guru baik aspek kognitif, afektif maupun psikomotorik adalah dengan mengadakan pelatihan bagi guru (Malta, 2013). Sebagaimana sekolah yang lain, SDN Demangan 2 Bangkalan juga berkeinginan untuk meningkatkan kualifikasi dan kemampuan guru, sehingga setiap guru mampu menjalankan fungsinya secara optimal. Untuk mengembangkan kreativitas guru dalam menggunakan Ms PowerPoint maka diadakanlah pelatihan membuat media pembelajaran interaktif berbasis IT menggunakan Ms PowerPoint dengan Macro bagi guru-guru di SDN Demangan 2 Bangkalan. Pada saat pelatihan dimulai dengan pengenalan Ms PowerPoint para peserta terlihat sangat antusias, namun saat materi sudah sampai pada Macro tampak para peserta mulai mengalami kesulitan dan stress. Hal ini menunjukkan bahwa taraf kesulitan materi mempengaruhi motivasi peserta pelatihan. Ini berarti apabila materi pelatihan mempunyai taraf kesulitan yang tinggi maka peserta pelatihan menjadi kurang termotivasi, namun motivasi justru akan meningkat jika materi pelatihan dipandang mudah (Yogasuria, 2015). 
Fakta yang terjadi saat pelatihan berlangsung sangat menarik untuk dikaji, khususnya tentang faktor-faktor yang mempengaruhi efektivitas suatu pelatihan. Berdasarkan kajian empiris, efektif tidaknya suatu pelatihan dipengaruhi oleh banyak factor, seperti tingkat reaksi, tingkat pembelajaran, tingkat perubahan perilaku (Rustiana, 2010), kompetensi dan desain penelitian (Sela, Lengkong, \& Trang, 2018). Efektivitas pelatihan tercermin dari perubahan perilaku, pengetahuan yang bertambah, dan kinerja yang meningkat (Putra \& Prasetya, 2017), perubahan sikap, pengetahuan dan keterampilan (Rumidjan, Sumanto, Sukamti, \& Sugiharti, 2017). Dalam penyelenggaraan pelatihan, kendala seringkali bersumber dari beragamnya kemampuan para peserta. Ada peserta yang cepat menangkap, ada pula yang lambat. Terkadang lambatnya kecepatan peserta dalam menyerap materi menyebabkan durasi waktu yang sudah ditetapkan di awal terkesan kurang bagi peserta (Yogasuria, 2015).

Dari fenomena ini maka ingin diketahui efektivitas pelatihan yang dirasakan oleh para peserta pelatihan dengan melakukan analisis factor instruktur dan materi pelatihan, apakah instruktur dan materi berpengaruh terhadap efektivitas pelatihan pembuatan media pembelajaran interaktif berbasis IT bagi para guru?

\section{KAJIAN PUSTAKA}

\section{Instruktur}

Berdasarkan pendekatan konstruktivis social, instruktur lebih berperan sebagai fasilitator dari pada sebagai pengajar (Suyono \& Hariyanto, 2011). Peran fasilitator lebih pada membantu peserta pelatihan untuk memperoleh pemahamannya sendiri terhadap materi bahasan/ pelatihan. Agar peserta pelatihan dapat berperan aktif, maka seorang instruktur harus memiliki keterampilan yang lebih dari sekedar mengajar. Dalam hal ini kemampuan komunikasi menjadi sesuatu yang sangat penting bagi seorang instruktur karena harus mengakomodasi dialog yang kontinyu selama pelatihan sedang berlangsung.

\section{Materi Pelatihan}

Materi atau bahan ajar memiliki peran yang penting dalam pelatihan. Materi pelatihan berisi uraian materi yang harus dipelajari oleh para peserta pelatihan. Materi pelatihan dipersiapkan oleh seorang instruktur dalam bentuk modul panduan pelatihan. Modul pelatihan dibuat rinci dan sistematis dengan bahasa yang mudah dipahami agar para peserta pelatihan dapat mereview secara mandiri tanpa mengalami kesulitan yang berarti.

\section{Efektivitas Pelatihan}

Efektivitas pelatihan merupakan hal yang sangat penting terutama untuk mengembangkan kompetensi SDM termasuk guru. Efektivitas pelatihan dipengaruhi oleh berbagai proses baik sebelum, selama, atau sesudah diselenggarakannya pelatihan. Fauzan mendefinisikan efektifitas pelatihan sebagai ketepatan dari pelaksanaan suatu pelatihan, atau tingkatan dari proses pelatihan yang menghasilkan output yang tepat pada tempat yang benar, waktu yang tepat dan harga yang pantas (Sela, Lengkong, \& Trang, 2018).

\section{Media Pembelajaran Interaktif dengan Macro PowerPoint}

Terciptanya pembelajaran yang interaktif tentunya menjadi harapan setiap guru. Untuk menciptakan pembelajaran yang interaktif, guru perlu menyiapkan sarana dan prasarana salah satunya media pembelajaran interaktif berbasis komputer. Media pembelajaran interaktif dapat meningkatkan kemampuan berpikir, kreativitas dan 
kemampuan mengkonstruksi pengetahuan baru pada siswa sehingga siswa memiliki penguasaan yang baik terhadap materi pelajaran.

Pembelajaran berbasis komputer adalah pembelajaran yang menggunakan alat bantu komputer (Wena, 2009). Dalam hal ini guru memanfaatkan komputer untuk menyampaikan materi kepada siswa dan siswa terlibat atau berinteraksi langsung dengan media komputer ini. Tentusaja hal ini akan menjadi pengalaman belajar yang menarik dan menantang bagi siswa. Setiap siswa memiliki pengalaman dan kesan tersendiri saat berinteraksi dengan komputer dalam proses pembelajaran.

Membuat slide PowerPoint dengan Macro akan menghasilkan tampilan slide yang jauh lebih interaktif, sebagaimana gambar berikut :

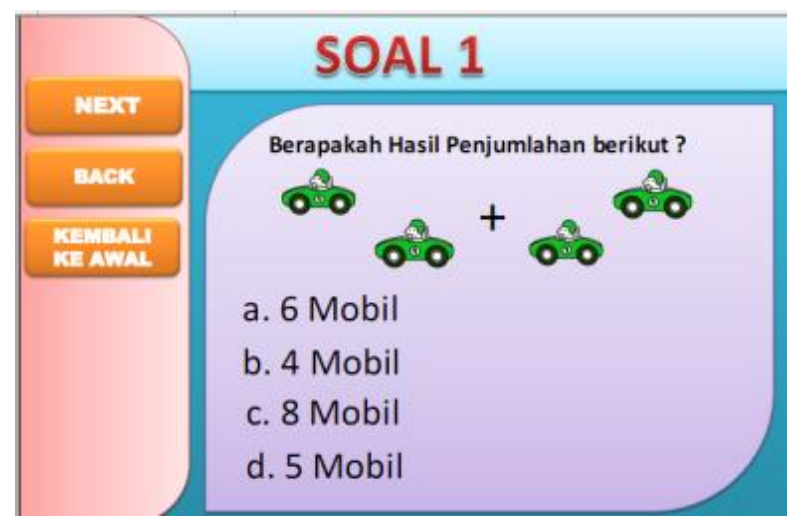

Gambar 1.

Tampilan Slide Soal dengan Macro PowerPoint

Cara menyelesaikan soal adalah siswa diminta untuk klik jawaban yang dianggap benar. Setelah semua soal terjawab, maka siswa bisa mengecek skor, sebagaimana tampilan slide pada gambar berikut:

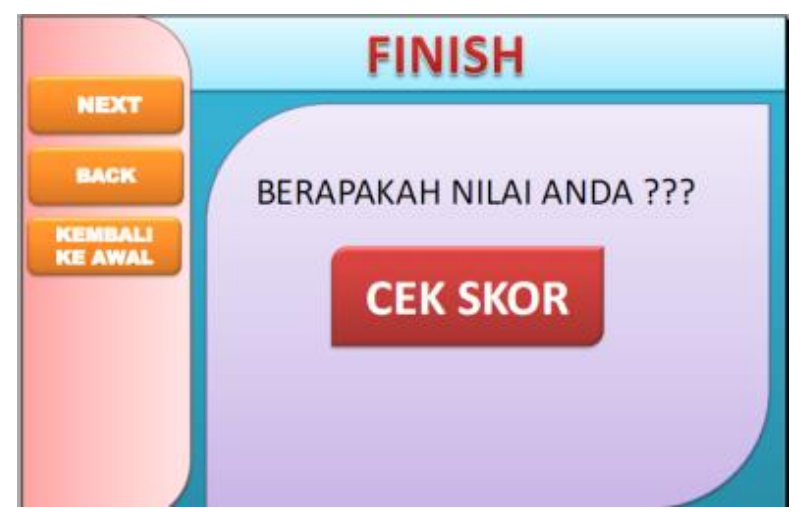

Gambar 2.

Tampilan Slide Konfirmasi Skor dengan Macro PowerPoint

\section{METHODS}

Pendekatan dalam penelitian ini adalah pendekatan kuantitatif. Penelitian ini termasuk penelitian asosiatif karena meneliti hubungan antar beberapa variabel. Variabel yang digunakan pada penelitian ini adalah efektivitas pelatihan $(\mathrm{Y})$, instruktur $\left(\mathrm{X}_{1}\right)$, 
materi pelatihan $\left(\mathrm{X}_{2}\right)$. Populasi dalam penelitian ini adalah guru-guru SDN Demangan 2 Bangkalan yang mengikuti pelatihan membuat media pembelajaran yaitu sebanyak 11 orang guru. Seluruh anggota populasi diambil sebagai sampel. Data dikumpulkan melalui kuesioner. Kuesioner disusun berdasarkan variabel penelitian dan indikator penelitian dengan skala pengukuran instrument menggunakan skala likert. Tehnik analisis menggunakan analisis uji statistik yaitu uji $\mathrm{F}$ dan uji t. Uji $\mathrm{F}$ digunakan untuk menguji signifikansi variabel instruktur dan materi terhadap efektivitas pelatihan. Uji t digunakan untuk menguji signifikansi pengaruh instruktur terhadap efektivitas pelatihan, dan pengaruh materi terhadap efektivitas pelatihan.

\section{RESULTS \& DISCUSSION}

\section{Hasil Penelitian}

Uji asumsi klasik meliputi uji multikolinieritas dan heteroskedastistas.

1. Uji Multikolinearitas

Uji multikolinearitas dilakukan dengan bantuan SPSS 23.0 for Windows ditunjukkan oleh tabel coefficient dengan mengamati kolom tolerance dan kolom VIF. Didapatkan nilai tolerance kedua variabel $0,893>0,1$ dan nilai VIF kedua variabel $1,120<10$. Dengan demikian tidak ada multikolinearitas antara variabel bebas dalam model regresi.

2. Uji Heteroskedastisitas

Uji heteroskedastisitas, menggunakan uji Rank Spearman dengan bantuan SPSS 23.0 for Windows. Didapatkan signifikansi untuk $X_{1}=0,641>0,05$, untuk $X_{2}=$ $0,205>0,05$. Dengan demikian hasil uji Rank Spearman menunjukkan pada model tidak terjadi heteroskedastisitas.

3. Uji Regresi

Model regresi yang diperoleh berdasarkan hasil penelitian, dapat dituliskan dalam bentuk persamaan regresi sebagai berikut: $Y=-3,022+0,908 X_{1}+0,212 X_{2}$. Dari persamaan tersebut, kedua variabel bebas memiliki koefisien regresi dengan arah positif. Hal ini berarti bahwa semakin kompeten seorang instruktur, dan materi yang rinci, sistematis dan mudah dipahami akan meningkatkan efektivitas pelatihan.

Hasil uji $\mathrm{F}$ berdasarkan uji ANOVA atau uji statistik F, model menunjukkan nilai $F$ sebesar 5,228 dengan probabilitas sebesar 0,035. Nilai signifikansi tersebut lebih kecil dari 0,05. Hal ini berarti bahwa efektivitas pelatihan dapat dijelaskan oleh variabel instruktur dan materi pelatihan secara bersama-sama atau dengan kata lain semua variabel bebas secara bersama-sama merupakan penjelas yang signifikan terhadap variabel terikat.

Hasil uji parsial menunjukkan tidak semua variabel memiliki pengaruh signifikan. Uji parsial menunjukkan variabel instruktur memiliki nilai thitung sebesar 2,638 dengan signifikansi 0,030 dan variabel materi pelatihan memiliki nilai $t$ hitung sebesar 0,904 dengan signifikansi 0,392. Berdasarkan tingkat signifikansi, variabel materi tidak mempengaruhi efektivitas pelatihan.

Adjust R Square sebesar 0,458 berarti 45,8\% efektivitas pelatihan dipengaruhi oleh factor instruktur dan materi sedangkan $54,2 \%$ dipengaruhi oleh variabel lain diantaranya desain pelatihan, kompetensi peserta pelatihan, dan sebagainya.

\section{Pembahasan}

\section{Instruktur dan materi pelatihan terhadap efektivitas pelatihan}

Hasil penelitian menunjukkan bahwa factor instruktur dan materi pelatihan secara bersama-sama berpengaruh signifikan dan positif terhadap efektivitas pelatihan. 
Implikasi dari temuan tersebut adalah semakin kompeten seorang instruktur, dan materi yang rinci, sistematis dan mudah dipahami akan meningkatkan efektivitas pelatihan.

\section{Instruktur pelatihan}

Instruktur berpengaruh signifikan dan positif terhadap efektivitas pelatihan. Instruktur yang kompeten baik secara pengetahuan kognitif, keterampilan, serta kemampuan komunikasi akan meningkatkan efektivitas dari suatu pelatihan. Instruktur yang mampu membangun komunikasi yang hangat dengan peserta akan mendorong peserta pelatihan untuk lebih aktif (berani) bertanya atau mengajak instruktur untuk berdiskusi dalam rangka menjawab sesuatu yang belum dipahaminya.

\section{Materi pelatihan}

Materi pelatihan tidak berpengaruh signifikan terhadap efektivitas pelatihan. Sesulit apapun suatu materi pelatihan tidak berdampak signifikan terhadap keberhasilan suatu penelitian jika instruktur yang mendampingi pelatihan tersebut kompeten. Instruktur yang kompeten akan membuat materi pelatihan yang cukup sulit menjadi terasa lebih mudah untuk diikuti. Instruktur yang kompeten memiliki kemampuan menyederhanakan suatu materi yang rumit.

\section{CONCLUSION}

Dari pembahasan yang telah diuraikan maka dapat ditarik simpulan bahwa : 1) factor instruktur dan materi pelatihan secara bersama-sama berpengaruh signifikan dan positif terhadap efektivitas pelatihan, 2) Instruktur berpengaruh signifikan dan positif terhadap efektivitas pelatihan, dan 3) Materi pelatihan tidak berpengaruh signifikan terhadap efektivitas pelatihan. Kendati materi tidak berpengaruh signifikan bukan berarti variable materi pelatihan menjadi sesuatu yang sepele, materi pelatihan harus mendapat perhatian dari penyelenggara pelatihan untuk mampu menyajikan modul pelatihan yang sistematis, rinci, dan bahasanya mudah dipahami agar peserta pelatihan dapat mereview secara mandiri di luar waktu pelatihan.

Pengetahuan dan kemampuan berkomunikasi dari seorang instruktur lebih urgen dibandingkan materi pelatihan itu sendiri sehingga sebuah materi pelatihan yang memiliki tingkat kesulitan tinggi harus disertai dengan instruktur yang memiliki kompetensi untuk menyederhanakan materi sehingga terasa lebih ringan oleh peserta pelatihan.

\section{REFERENCES}

Malta. (2013). Efektivitas Pelatihan dalam Meningkatkan Kompetensi Tutor Tutorial Tatap Muka pada Universitas Terbuka (Kasus: Tutor pada Universitas Terbuka Di Provinsi Aceh). http://journal.unisla.ac.id/pdf/116122013/Malta_Aceh.pdf , 17.

Putra, A. R., \& Prasetya, A. (2017). Analisis Efektivitas Pelatihan Karyawan ke Luar Negeri (Studi pada PT. Jakarta International Container Terminal) . Jurnal Administrasi Bisnis (JAB) Vol. 47 No. 1 Juni , 39-46.

Rumidjan, Sumanto, Sukamti, \& Sugiharti, S. (2017). Pelatihan Pembuatan Media Pembelajaran untuk Meningkatkan Kualitas Pembelajaran bagi Guru Sekolah Dasar. ABDIMAS PEDAGOGI, Vol 1 No 1, Oktober, 77-81.

Rustiana, A. (2010). Efektifitas Pelatihan bagi Peningkatan Kinerja Karyawan. Jurnal Dinamika Manajemen Vol 1 No 2 , 137-143. 
Sari, I. P., Sari, M. N., \& Miftah, Z. (2019). Pelatihan Membuat Media Pembelajaran Interaktif Berbasis Teknologi Informasi . Jurnal PKM: Pengabdian kepada Masyarakat Vol. 02 No. 02, Mei-Agustus , 119-126.

Sela, J., Lengkong, V. P., \& Trang, I. (2018). Pengaruh Kompetensi dan Desain Pelatihan terhadap Efektivitas Pelatihan Guru SMA/SMK/MA Manado pada Dinas Pendidikan Daerah Provinsi Sulawesi Utara. Jurnal EMBA Vol.6 No.4 September , $2368-2377$.

Soenarko, B., Wiguna, F. A., \& dkk. (2018). Pelatihan Pembuatan Media Pembelajaran Interaktif dengan Memanfaatkan Bahan Bekas untuk Guru Sekolah Dasar pada Anggota Gugus 2 Kecamatan Ringinrejo Kabupaten Kediri. Jurnal ABDINUS Vol 1 No 2 , 96-106.

Suyono, \& Hariyanto. (2011). Belajar dan Pembelajaran Teori dan Konsep Dasar. Bandung: PT Remaja Rosdakarya Offset.

Uno, H. B., \& Mohamad, N. (2011). Belajar dengan Pendekatan PAILKEM Pembelajaran Aktif, Inovatif, Lingkungan, Kreatif, Menarik. Jakarta: Bumi Aksara.

Wena, M. (2009). Strategi Pembelajaran Inovatif Kontemporer Suatu Tinjauan Konseptual Operasional . Jakarta: Bumi Aksara.

Yamin, M. (2013). Kiat Membelajarkan Siswa. Ciputat: GP Press Group.

Yogasuria, E. (2015, Februari 10). Media Pembelajaran Interaktif. Retrieved Februari 29, 2020, from http://www.bbpp-lembang.info: http://www.bbpplembang.info/index.php/arsip/artikel/artikel-manajemen/843-mediapembelajaran-interaktif 